\title{
Study on the Transformation and Development of Private Colleges and Universities
}

\author{
Yao Zhang ${ }^{1,}$ a and $\mathrm{Na}$ Song ${ }^{1, b}$ \\ ${ }^{1}$ College of Information Engineering, Zhengzhou University of \\ Industrial Technology, Xinzheng, China \\ a304963405@qq.com, b285423508@qq.com
}

\begin{abstract}
Keywords: Private Colleges and Universities; Transformation; University of Applied Science and technology; Strategy
\end{abstract}

\begin{abstract}
In this paper, the present situation and the difficulties faced by private undergraduate colleges and universities, based on the analysis of the necessity of the transformation and development of private colleges and universities, focusing on the direction and content of the transformation and the driving force. On this basis, this paper draws the conclusion that it is of great significance to construct the University of science and technology, and to realize the sustainable development of private colleges and universities.
\end{abstract}

\section{The Development of Private Colleges and Universities in China}

First, the source of funding is relatively simple. Since the establishment of private colleges, the tuition fee is an important source of funding, and the channel is relatively single. High tuition so that the general condition of the family daunting candidates, will affect enrollment. Because the schools lack of funds, many private universities do not have enough funds to purchase the teaching and experiment instrument, resulting in equipment obsolete, directly affect the quality of teaching.

Second, professional and curriculum features. Private colleges and universities have been affected by the public colleges and universities because of their lack of experience in running schools and the lack of market research. For example, in professional settings, according to the survey, in Henan Province, the vast majority of private universities offer such as computer, English, marketing, accounting and other professional, but like machinery, measurement and control, communication engineering into a larger engineering major is not much, this caused the situation of similar professional college settings, no the characteristics of [1-3].

Third, the unreasonable structure of teachers. Due to the nature of private colleges and universities, in order to save money, the teachers including full-time teachers and part-time teachers, part-time teachers generally taken by semester or year of employment, has the characteristics of strong liquidity, and part-time teachers of the school regulations do not understand the deep, strong sense of responsibility, work state is loose, to a certain extent affected the quality of teaching. The majority of private college teachers structure is not reasonable, just graduated from college students and the current or previous research at the age of sixty or over public university retired teachers accounted for a larger proportion, and the cultivation of the subtropical high school or above their teachers less.

Fourth, source reduction, poor quality. Due to the implementation of family planning in the last century in $80 \mathrm{~s}$ and $90 \mathrm{~s}$, resulting in the total number of students attending the college entrance examination in recent years continued to decline, resulting in fewer students. In addition, the tension of private college students, leading to many private colleges and universities can not achieve the desired size. Two students are poor quality. The admission of private college students in general for the third batch of volunteers, after admission to the same level of public university admissions, which means that private college students admitted to public universities is lower than the score [4]. As a result, the improvement of teaching quality is also difficult.

Fifth, the management system is not standardized. The majority of private university founded by the enterprise, do not know how deep the teaching management mode, but take the enterprise management or family management model, the related system is not suitable for the constraints of 
the work of teachers, with the office to engage in teaching, which restricts the development of school[5].

Sixth, teachers' scientific research ability is poor. First of all, due to the limitations of private colleges and universities, the majority of colleges and universities experimental equipment obsolete, only to meet the needs of normal teaching, far from being able to meet the needs of teachers to conduct in-depth research. Second because the private colleges to a small number of teachers, the teaching task, some teachers also undertake certain administrative tasks, so the teachers to carry out scientific research, these two main factors determine the research ability of teachers in private colleges should be improved.

\section{The Necessity of the Transformation of Private Colleges and Universities in China}

The distribution of personnel of the situation in China is lack of high-level talents, but most of the local undergraduate university still emphasizes on the theoretical study and practice of training look. However, the results of the survey shows that the social demand for professional and technical personnel of $30 \%$, the management, production, service and other positions of the talent needs of about $60 \%$. It can be seen that the society does not need too much research talent, but the need for a large number of technical personnel. This makes the undergraduate colleges and universities to train out a lot of research talent surplus, and social needs. Therefore, the training of private colleges and universities cannot meet the needs of social development [6-8].

February 2014, Li Keqiang put forward at the State Council executive meeting, to focus on employment, to guide a number of ordinary undergraduate colleges and universities to the application of the national social needs of University of science and technology transformation. Visible, the construction of University of science and technology is no longer the trend of a place, but the state from the social needs, the development of China's universities, industrial upgrading and optimization of the national level strategy.

\section{A Strategic Studies about Private University Transform to the Science and Technology Application of University in China.}

The National Policy Support the Research about the Transformation of the Private University. First point is to improve the government subsidies for Private University. Most of the Private University exists in a second-tier cities, the running cost of school is higher. The high tuition fees make many rural students, need take out money to fund from government to ease their burden. The state financial support for Private University also an embodiment of education fairness [9-11].

Second point is to make Private University more independent development. On the one hand, considering the advantage of its system and mechanism, independent development can better promote the development of colleges and universities; On the other hand is to promote the development of higher education experience. Is combining the reality of running schools, to be solved urgently, Private University chaos to collect fees, set up professional demands such as nonstandard and admissions.

Third point is to speed up the Private University transformation from quantity to quality. National higher education development has "high level" Private University construction on the key projects, the development of Private University represents the country's new hope and new requirements. But only put forward the slogan of "a" high level, the lack of a specific plan. Suggest real education department attaches great importance to the construction on the high level demand in university, as soon as possible design scheme of the pilot reform, bring up a batch of national high level as early as possible scheme run by the local universities, thus promote the national Private University transformation, promote the development of the national education.

The Role and Function of Enterprises and Institutions to the Transformation of Private University. Private University to cultivate applied talents, and improve the skill level of the applied talents and is about to open education, make enterprises to participate in the training process. Only in this way, cultivating people is the real society and the enterprise need, can play the role and value 
of applied universities. There are a lot of by using the method of university-enterprise cooperation training applied talents, which accounts for the mainstream: university-enterprise cooperation in talent cultivation plan, university-enterprise cooperation to develop the project of talent cultivating, university-enterprise cooperation construction applied characteristic, university-enterprise cooperation open courtyard department, university-enterprise cooperation writing textbooks, university-enterprise cooperation cultivating "double type" teachers, university-enterprise cooperation to provide internships, etc.

Private University can't theory research as a key development, but rather to combinative oneself is actual, giving full play to the advantages of system, the construction and development focus on social needs and the enterprise needs, to develop the application of scientific research, in improving the capability of independent innovation at the same time, keep close contact with enterprises.

University-enterprise cooperation to achieve technology research and development and promotion, the main ways are: enterprise commissioned the study, the exchange of personnel between colleges, university-enterprise cooperation declared national and province (city) scientific research subject, university-enterprise cooperation scientific research platform construction, colleges and universities to provide the latest scientific research achievements to the enterprise, promoting cooperation between colleges and university-enterprise cooperation technology research and development of economic entities, university-enterprise cooperation union manufacture-learning-research cooperation, etc.

The Strategy Transformation of Private University Itself. Autonomy in Private University is to realize the goal of running qualification and ability. Private University in order to ensure a steady transition to an university of science and technology, can consider to Private University to strengthen school-running autonomy in three aspects: one is to reform the current system of selection of the recruitment of students test. At present the disadvantages of performance in the recruitment of students test selection system, after nine years of compulsory education students, or continue to the ordinary high school, or go to secondary vocational high school. The reality is, however, the development of secondary vocational high school space is narrow, cause most of the students prefer to study in ordinary high school, this makes secondary vocational high school students is becoming worse. The recruitment of students test selection system is unreasonable, there are many difficulties, leading to the development of higher vocational education so as to make the higher education personnel training and the demand of the social and economic development, which affects the rationality of the education system. Second, expanding Private University introduce teacher autonomy, around the goal of university of science and technology transformation to the application, strengthen the introduction of teachers, set up a "double division type" teacher training system, give full play to the role of the cooperation between colleges and make more business practice, teachers have the opportunity to improve the ability of engineering practice, in addition, Private University also should publish relevant policy, attracting outstanding engineering and technical personnel to enter industry enterprises run by the local college part-time, guide students to practice. Three is to increase Private University of professional Settings. Under the guidance of the competent department of the higher education, local economic development situation, setting the specialty catalog or professional direction, at the same time, according to the feedback of employment, the employment situation is not ideal even stop recruit professional in time to reduce enrollment plan, build up professional dynamic adjustment mechanism.

Is of important guiding significance for theory to practice, to develop Private University to the application research concerning the transformation of university of science and technology work, ideas, and to summarize experience in time and be promoted. Proposed the application of science and technology university union or official or private organizations such as the application of university of science and technology association, assist departments run by the local education in colleges and universities to apply to guide the work of the development of the university of science and technology transformation, guarantee of government public decision-making forward-looking and scientific, so as to reflect a wider range of public opinion and social basis. 


\section{The Development Prospect of Private Colleges in China}

School orientation to the "application type" change. Under the basic law of higher education, we should carry out practical problems such as "the integration of production and education, the cooperation between schools and enterprises," the orientation of running a school, improve the quality of teaching, optimize the professional setting, enhance the level of teachers and strengthen the application research. School orientation should be applied to technology development and application of technical personnel training as the primary task to serve the local construction.

Professional structure to the "demand-oriented" change. Private colleges and universities in the transition to closely around the province to develop the actual situation, understand and study the province, combined with the actual development needs of the province to adjust the professional settings for local economic development services, the school and local seamless docking to meet the needs of local and industrial development The To adjust the industrial structure to promote professional reform, scientific and technological progress-driven curriculum reform, to achieve professional and industry, post docking, education and local industry docking, and social common development.

Personnel training to "ability-oriented" change. University education should not be limited to the knowledge of teaching materials, students in addition to the textbooks on the knowledge, the more important is to develop their own learning ability, so that in the future workplace to have the ability to self-learning. It is aimed at cultivating students 'knowledge application ability, hands practical ability and innovation ability. It is aimed at cultivating students' ability of knowledge application.

Teachers to the "double-qualified dual-type" change. The construction of faculty is based on the strengthening of teachers' teaching ability, and gradually tilts to the construction of "double teacher" and "double teacher quality" teachers, which allows young teachers to work in enterprises and cooperate with enterprises. To build a rich professional knowledge of the theory, but also a solid practical ability of enterprises, "double-dual-type" professional team of teachers.

\section{Conclusion}

Redefine the concept of running a school, the combination of theoretical study and practical operation, establish and improve the service of social and economic development and industrial innovation and innovative talents training mechanism in order to make private universities and regional economy to promote the coordinated development of each other, the formation of a virtuous circle, Realize the transformation and upgrading of private colleges and universities, system innovation, cultivate more social needs of the application of talent, enhance the overall income, highlight the social value, and promote the development of national education.

\section{References}

[1] R.M. Zhang. Cohesion of Consensus to Promote Reform to Promote Sustainable and Healthy Development of Private Education [J]. Journal of Zhejiang Shuren University, (2013)No. 1,p.1.

[2] W.X. Wang. China's Private Colleges and Universities Analysis of the Status quo and its Development Strategy [J]. Education and occupation, (2014 )No. 36,p. 25.

[3] W. Xiao, J.X Gao. Discussion on the Scientific Development Concept and the Harmonious Construction of Higher Education [J]. Educational Science Forum, (2007) No.1,p. 6.

[4] Z.Q Yang. Scientific Development Concept under the Guidance of Private Schools Management Strategy [J]. Educational Decision and Management, (2007) No.3,p11.

[5] X.P. Yan. From Exploration to Transformation: Relying on "two industry and two domains" to Build the Application of Technology University Thinking and Practice [J]. University (Research Edition), (2014) No.9,p 43.

[6] Z.W. Mao. Research on the Transformation and Development of Newly-built Undergraduate Colleges to Applied Undergraduate Universities - Taking Jiangxi Province as an Example [D]. Nanchang: Jiangxi Normal University, 2015. 
[7] Y.H. Liu. On the Necessity of the Transformation and Development of Local Undergraduate Colleges in China [J]. Hebei Enterprise, (2015) No.12,p 111.

[8] L.M. Wang, X.F. Kong. Comparative Study of National Policy on the Development Orientation and Support of Private Colleges and Universities [J] .Heilongjiang Higher Education Research, (2014) No.10,p 94.

[9] R.F. Li. A Comparative Study of the Policy of Higher Education in China and the United States (Private) [D].Nanchang: Nanchang University master 's degree thesis, 2010.

[10]H. Wu, W. Hu. Public Finance Why to Subsidize Private Education [J]. Peking University Education Review, (2012) No.2,p 20.

[11] L.L. Liu. Research on the Development of Private Higher Education in China [M]. Changchun: Jilin People's Publishing House, 2002. 